\title{
DE BESTRIJDING VAN HET GEBRUIK EN HET MISBRUIK VAN STERKEN DRANK, IN VERBAND MET DEN ACCIJNS OP GEDISTILLEERD EN DE VER- VALSCHING VAN DIEN DRANK.
}

Bij vele bestrijders vau het draukverbruik in Nederland, bestaat de meeniug dat verhooging van de belasting op gedistilleerd, geen beperkende invloed op het verbruik heeft, en dat accijus verhooging een voor de volksgezondheid verderfelijke werking heeft, doordien zij vervalsching van den sterken drank ten gevolge heeft. Buiten Nederland wordt die meening door zeer enkelen, en in Nederland waarlijk niet door allen verdedigd. Gelukkig! Echter blijkt deze overtuiging, onder meer, uit het adres van 22 Oct. 1904, tegen accijnsverhooging, ann de Tweede Kamer der Staten-Generaal ingezonden, door het Hoofdbestuur van de Nederlandsche Vereeniging tot afschaffing van Alcoholhoudende dranken.

Het is zeker gewaagd; een zoo algemeen gevestigde overtuiging door ervaring en onderzoek ontstann te bestrijden, en als ik daartoe in de volgende bladzijden overga, dan geschiedt zulks in het belang van de Vereenigingen, die draukbestrijding ten doel hebben, en niet om de, ook door mij erkende gunstige resultaten hunner pogingen afbreuk te doen. Immers worden door de kennis der juiste oorzaken van het verminderd alcoholverbruik, de middelen aangegeven voor de meest doelmatige wijze, waarop het sterke drankverbruik kan bestreden worden.

Als vervalsching van sterken drank, kan naar het beginsel der drankbestrijders, alleen in aanmerking komen, het bijvoegen van stoffen, die voor de gezondheid minstens e ven schadelijk zijn als het gedistilleerd. Alle andere menging kunneu zij niet afkeuren, want daardoor wordt de alcohol niet méér maar minder schadelijk voor de gezondheid. Wel worden daardoor de koopers in zekeren ziu bedrogen, zooals door vervalsching van zoovele leveusmiddelen of dranken, mar als motief 
tegen accijnsverhooging kunnen zij niet in aanmerking komen.

Voor schadelijke vervalsching komen slechts twee stoffeu in aaumerking, amijlalcohol (foesel) en methijlalcohol (houtgeest), welke beide nog in meerdere mate dan aethijlalcohol (gewoon gedistilleerd-) schadelijk zijn voor de gezondheid. Van bijmenging van andere stoffen van eenige beteekenis, is niets gebleken, en bij een door mij ingesteld onderzoek bleek slechts, dat soms door tappers in Drenthe, in het vat met jenever een bus met peper was gedaan. Dit is geen schadelijke vervalsching, het geschiedt om aan den smaak van sommige drinkers te voldoen, die de jenever beter vinden, naarmate ze meer prikkeling veroorzaakt. Fr wordt wel beweerd dat vitriool en water bij de jenever wordt gevoegd, maar de smaak wordt daardoor anders, en rij die dagelijks jenever drinken kennen de zuivere jeneversmaak te goed, om zich daardoor te laten bedriegen, bovendien is dergelijke vervalsching niet kumnen angetoond worden. Volgens veler overtuiging is jenever zonder de waarde er van te verminderen, weinig geschikt om vervalscht te worden met stoffen schadelijker voor de gezondheid dan de drank zelf, zoodat alleen blijft te ouderzoeken of bijmenging plaats heeft met foesel of houtgeest.

In No. 25 van het Orgaan van deu Volksbond "Vereeniging tegen Drankmisbruik", komt voor een rapport van het Hoofdbestuur, betreffende den omvang van het gebruik van brandspirit us als genotmiddel. Deze spiritus bevat op 9 liter, één liter houtgeest en is als drank geheel ongeschikt. Volgens genoemd rapport, zouden naar verkregen informatiën, zonder dat bepaalde feiten werden geconstateerd, in enkele gevallen, zeer laag gezouken dronkards de ondriukbare braudspiritus drinken. Daartegen ziju geen maatregelen te nemen. Ten behoeve der iudustrie moet de fiscus vrijdom van accijns verleenen voor spiritus, nadat die vooraf ondrinkbaar is gemankt. De houtgeest mankt ze werkelijk ondrinkbaar, zoodat het gebruik daarvan als drank nimmer vau eenige beteekenis kan worden en alleen verdierlijkte droukaards dat vocht soms zulleu drinken.

Op uitnoodiging van het Hoofdbestuur van den "Volksbond" "Vereeniging tegen drankmisbruik" heeft Prof. Dr. H. W e fers Bettink te Utrecht, een wetenschappelijk onderzoek ingesteld naar de mate vau vervalsching van sterken drank. De uitkomsten van dat ouderzoek zijn vervat in een rapport, opgenomeu 24, April 
1902 , in No. 19 van het orgaan van den Volksbond. Daaruit blijkt dat van 82 monsters drank is onderzocht of zij foesel, en van 76 of zij houtgeest bevatten.

Wat betreft de vervalsching met amijlalcohol (foesel) moet worden opgemerkt, dat gewone jenever steeds een klein deel fuesel bevat, die reeds bij het stoken van gedistilleerd, daarin als bijproduct ontstaat, en daaruit niet door filtratie verwijderd wordt. Die foesel geeft an jenever de smaak en is er een noodzakelijk bestanddeel van. De volksmond spreekt dat uit waar ze jenever "foesel" noemt, en een glas "foesel" vragende, daarmede jenever bedoelt. Dit in aanmerking nemende, is het opmerkelijk dat volgens genoemd rapport in 55 van de 82 onderzochte monsters geen foesel is gevonden, en in l mouster sporen daarvan, terwijl in 19 monsters minder dan 1 pCt. foesel aanwezig bleek. Deze 75 monsters waren derhalve niet vervalscht door bijmenging van foesel. Van de overige 7 monsters, bevatten 4 tusschen 1 en 2 pCt. foesel en 3 van 2-3 pCt. foesel. Waarschijnlijk ziju deze laatste monsters evenmin door toevoeging van foesel vervalscht. Foesel bevat ongeveer $95 \mathrm{pCt}$. amijl-alcohol, zoodat toevoeging van foesel, zonder den drank te verslappen, aanlenging met een even groote hoeveelheid water toelaat. Het daardoor te behalen voordeel is echter bij toevoeging van ongeveer 2 pCt. foesel zoo gering, dat geen tapper daardoor de smaak van den drank zal bederveu, want evenzeerals een kleine hoeveelheid de goedesmak aan de jenever geeft, wordt diebedorven door te groote hoeveelheid foesel. Onze grensbewoners zijn daarmede wel bekend, de Duitsche jenever valt niet in hun smak en dat komt omdat er te groote hoeveelheid foesel in aanwezig is. Om diezelfde redenen kan de anwezigheid van meer dan 1 pCt. foesel in sommige der 82 onderzochte monsters verklaard worden. De jenever kan vervaardigd zijn uit minder goed graan, dat soms als grondstof voor gedistilleerd wordt gebruikt, onder meer, graan dat zeeschade heeft beloopen. Jenever vervaardigd uit spiritus bevat maar p. m. een derde van de foesel, die in de moutwiju-jenever aanwezig is en is uit een hygiënisch oogpant daarom minder schadelijk.

Door het onderzoek naar foesel, als voor de gezondheid schadelijk 
bijmengsel, is derhalve die vervalsching niet bewezen, eerder het tegendeel, doch bovendien kan zulke vervalsching iu de toekomst niet meer voorkomen. Bij arrest van den Hoogen Raad van 28 Juni 1897, opgenomen in de verzameling van wetten en voorschriften voor de ambtenareu der belastingen, jaargang 1904, No. 82 is beslist, dat amijl alcohol (foesel) geeu vreemd bestanddeel is van gewoon gedistilleerd, omdat volgens het gevoelen van door den Hoogen Raad gehoorde deskundigen aethijl- en amijl-alcohol gelijktijdig ontstaan bij de fabricage van gedistilleerd.

Die beslissing heeft ua lang beraad ten gevolge gehad dat van af $30 \mathrm{Juli} 1904$, amijlalcohol (foesel), evenals gewoon gedistilleerd onderworpen is aan den accijns naar de sterkte, en bij invoer van buiten 's lands bovendien belast is met invocrrecht, volgeus de Resolutie van den Minister van Financiën vall 30 Juli 1904. No. 131 (Verz. 83). De accijns van foesel bedrangt naar $95 \mathrm{pCt}$. alcohol, f $1.19 \frac{1}{2}$ de liter en bij invoer f 1.26 , een bedrag, dat vervalsching met zoo dure stof geheel uitsluit. Ontduiking van accijus van overigens vrij waardelooze foesel wordt gemakkelijk verhinderd. De gewone branderijen verkrijgen geen foesel als afgezonderd bijproduct. Zij wordt slechts verkregen door de enkele hier te lande gevestigde spiritus-fabrieken, die gezuiverde spiritus vervaarligeu. Deze zullen het bijıa waardeloos product niet met betaliug van accijns uitslaau, maar in de fabriek vernictigen. De foesel zal, nadat zij voor dat doel gezuiverd is, door welke bewerking de prijs eveneens hoog wordt, enkel nog dienst kunnen doen als middel van onderzoek, onder meer van melk of boter in Zuivelfabrieken, met vrijdom van accijns en onder de noodige contrôle tegen misbruik.

Het onderzoek van Prof. Dr. H. Wefers Bettink naar de vervalsching met methijl-alcohol (houtgeest) heeft volgens de in het rapport vermelde cijfers beter resultant opgeleverd. Een gevoel van afschuw moet de leden van deu "Volksbond" hebbeu bevangen bij het lezen van dat rapport. Zijn de daarin vermelde cijfers juist, dan zou gezegd kunnen worden, dat het Nederlandsche volk, direct werkend vergift wordt te drinken gegeven, maar gelukkig kụnneu zij niet waar zijn. Toch twijfelen de leden van den "Volksbond" niet aan de 
juistheid der in het "Orgaan" der Vereeniging gepubliceerde cijfers vall vervalschiug. zooals blijkt uit het e e verschenen V'erslag van het Hoofdbestuur nopeus het onderzoek naar den omvang van het gebruik van brandspiritus als genotmiddel, hiervoren reeds besproken, en waarin aan het slot de wenschelijkheid wordt uitgesproken, "dat het onderzoek"in 't vorige jaar door prof. dr. H. Wefers Bettiuk "met zoo groote welwillendheid en zoo voorbeel"dige toewijding verricht - zoo mogelijk worde "voortgezet eu uitgebreid in wijderen kring." De vragg dringt rich op, hoe is het mogelijk, dat die onware cijfers niet zijn weerlegd, komt het daardoor dat het "Orgaan" van den Volksbond uitsluitend door de leden wordt gelezen, en bezien die het vraagstuk slechts van ééne zijde? Eerst eenige dagen geleden kreeg ik keunis van het rapport van 24 April 1902, door toezending van No. 19 van het Orgaan door een lid van den Volksbond, met het doel om mij te overtuigeu vain den grooten omvang der vervalsching van sterken drank.

Volgens dat rapport, waarvan hier een uittreksel volgt, voor zooveel betreft de monsters waarin houtgeest is bevonden, bevatten van de 76 onderzochte monsters niet minder dan 12 groote hoeveelhedeu houtgeest (methijlalcohol).

Uittreksel ait het rapport.

\begin{tabular}{|c|c|c|c|c|}
\hline $\begin{array}{l}\text { Numwer } \\
\text { ran het. } \\
\text { monster. }\end{array}$ & $\begin{array}{l}\text { Afdeeling, } \\
\text { die het } \\
\text { monster } \\
\text { inzond. }\end{array}$ & $\begin{array}{l}\text { Procent- } \\
\text { gehaltie } \\
\text { aleohol. }\end{array}$ & $\begin{array}{l}\text { Procent- } \\
\text { gehalte aan } \\
\text { muthijl } \\
\text { alcohol. }\end{array}$ & 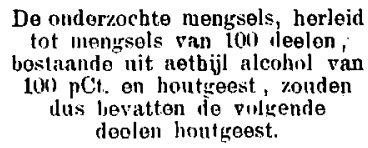 \\
\hline 8 & Aruhem & 37,2 & \pm 10 & $-1-26,9$ \\
\hline 13 & " & 38,84 & \pm 5 & $\pm 12,9$ \\
\hline 14 & Nijmegen & 39,64 & 上 2,5 & $-t \quad 6,3$ \\
\hline 19 & Zutfen & 36,72 & \pm 3 & $\pm \quad 8,0$ \\
\hline 27 & Wageningen & 38,24 & $-1: 5$ & $-13,0$ \\
\hline 32 & Doeshurg & 40,24 & $\pm \quad 2,5$ & I 6,1 \\
\hline 41 & Utrecht & 42,24 & \pm 4 & $\pm \quad 9,5$ \\
\hline 42 & $" 1$ & 37,44 & \pm 10 & $\pm 27,0$ \\
\hline 54 & Amsterdam & 38,34 & \pm 8 & $\pm 20,8$ \\
\hline 68 & Haarlem & $36,-$ & ㄴ 15 & $+41,7$ \\
\hline 72 & Rotterdam & 37,24 & 110 & $\pm 26,9$ \\
\hline 73 & $"$ & 35,44 & $-t 3$ & $\pm 8,4$ \\
\hline
\end{tabular}


Wat is de oorzaak van de verouderstelde vervalsching van sterke dranken door toevoeging van houtgeest?

De Staat verleent vrijdom van accijns voor spiritus van ten minste 85 pCt., nadat de drank als zoodanig onbruikbaar is gemankt door vermenging met houtgeest, een ondrinkbare alcohol met zeer onaangename smak en reuk. Bovendien kleurt zij de spiritus bruin. Deze vrijdom is het laatst geregeld bij Kon. besluit van 14 Sept. 1872 (Stbl. $n^{\circ}$. 89). Art. 7 bepaalt dat de vermenging moet geschieden met e en liter houtgeest op elke 8 liter gedistilleerd na herleiding tot de sterkte van 100 pCt. Het mengsel van 9 liter, zoogenaamde brandspiritus bevat dus op 100 deelen, $88_{\%}^{8}$ deelen aethijlalcohol van $100 \mathrm{pCt}$. en $11 \frac{1}{9}$ deel houtgeest.

Vervalsching van sterken drank door toevoeging van onvermengden houtgeest kan niet voorkomen, de drank wordt daardoor oubruikbaar, en er wordt geen voordeel door verkregen. Door vervalsching met houtgeest wordt bedoeld vervalsching met brandspiritus, die bevat $88 \frac{8}{9}$ deelen gewoon gedistilleerd van 100 pCt., waarvoor geen accijns is betaald, en $11 \frac{1}{9}$ deel houtgeest. De daarmede vervalschte drank kan derhalve nimmer méér, moet steeds minder dan $11 \frac{1}{9}$ deel houtgeest op 100 deelen bevatten en, zal er eenige kans ziju dat die drank koopers vindt tegen niet veel minder dan den gewonen prijs, véel minder dan $11 \frac{1}{9}$ deel.

$\mathrm{Bij}$ vermenging van twintig liter jenever van $40 \mathrm{pCt}$., met één liter brandspiritus van 85 pCt., kau daar nog bijgevoegd worden ruim een liter water om de jenever weer dezelfde sterkte te geven, die zij vóór de vermenging had. De hoeveelheid drank is nu ruim 22 liter en op den inkoopsprijs is $\mathrm{p}$. $\mathrm{m}$. 10 pCt. gewonnen, maar de reuk en de smaak van de houtgeest zijn er nog in te herkennen. Herleid tot alcohol vau 100 pCt., zou deze vervalschte drank op 100 deelen bevatten p. m. ],4 deel houtgeest. Het is nu duidelijk dat de onderzochte monsters, waarin groote hoeveelheden houtgeest zijn gevonden, niet gelijk waren aan de monsters door de afdeelingsbesturen van den "Volksbond" verzameld, door ankoop in tapperijen en kroegen, en het ligt op den weg vau het Hoofdbestuur van den "Volksboud", om door het instellen van een onderzoek aan het licht te brengen, door welke omstandighedeu, onder de autoriteit van een 
zoo geachten naam als die van Prof. Dr. H. Wefers Bettink, zulke, met de waarheid in strijd zijnde uitkomsten zijn gepubliccerd.

Door brandspiritus te vervormeu tot drank, heeft ontduiking van accijns op gedistilleerd plaats, en het is begrijpelijk dat de fiscus daartegen wankt.

Bij art. 22 van het anngehaald Kon. besluit van 14 Sept. 1872 (Stbl. 89) is strafbaar gesteld "het verkoopen of in voorraad hebben van sterken drank warin houtgeest annwezig is, in gebouwen wariu sterken drank verkocht of getapt wordt."

Die strafbepaling heeft aanhoudend onderzoek van drankmonsters ten gevolge gehad, zoolang de fiscus kon veronderstellen dat misbruik van de verleende accijnsvrijdom zou beproefd-worden. Vooral in de eerste jaren na het besluit vau 1872 is van dat contrôlemiddel gebruik gemaakt. Beter dan leden van vereenigingen zijn de ambtenaren van den fiscus in staat om het bedrog te ontdekken. Eerstgenoemden kunnen niet anders doen, dan monsters voor onderzoek in slijterijeu eu tapperijen te koopen, en moeten tevreden zijn met hetgeen de kooper hun geeft. De laatsten hebben het recht van visitatie, het recht om niet alleen in den winkel of in het trplokaal, maar ook in het woonhuis en andere lokaleu die er mede in gemeenschap zijn, naar voorhanden drank ouderzoek te doen, daaran te ruiken en er van te proeven, en ten slotte monsters, die tot behoud der identiteit worden verzegeld eu van opschriften voorzien, mede te nemen, van die der aanwezige drankken, die volgens hun speurzin het meest verdacht zijn. Behalve dere monsterneming die plaats heeft bij vermoeden van misbruik, heeft er herhaaldelijk van tijd tot tijd, een algemeene verzameling van monsters plaats gehad, voor een algemeen onderzoek. Het onderzoek der monsters geschiedt ann het laboratorium van het Departement van Financiën te Amsterdam. Onderzoek naar de hoeveelheid houtgeest is niet noodig, voor de strafbaarheid is het voldoende dat de anuwezigheid van houtgeest geconstateerd wordt.

Het resultaat van dat onderzoek gedurende vele jareu is geweest, dat slechts enkele bekeuringen noodig waren, zoodat de fiscus met grond kon beweren, dat vervalsching van sterken drank met brandspiritus slechts sporadisch voorkwam. Men is 
daarvan zoo overtuigd dat bij Kon. besluit van 31 Mei 1904 . (Stbl. 114) vrijzinniger bepalingen nopens de vermenging met houtgeest, met wijziging in zoover van het Besluit van 1872, zijn in werking getreden. Daarbij is tevens voor de braudspiritus, vermenging uitsluitend met donkeren houtgeest voorgeschreven, wardoor het gebruik van dat gedistilleerd als $\mathrm{d} r a n k$ ' $t$ welk enkele keeren voorkwam geheel wordt tegengegan.

In de eerste plaats wordt toegestann aan industriëelen, die dat noodig hebben, vrijdom van accijns door vermeuging met blanken houtgeest, echter onder voorwaardeu waardoor voorkomen wordt, dat het alzoo vermengde in den handel komt. Overigens is de accijnsvrijdom voor spiritus die wel in den handel komt en derhalve ook door particulieren als brandspiritus, zooals te voren kan gebruikt worden, en in winkels kan verkocht worden, gebleven, door vermenging uitsluiteud met donkeren houtgeest en wel met $7 \frac{1}{2}$ liter op elke 100 liter gedistilleerd na herleiding tot 100 pCt., zoodat die spiritus in plaats van $\frac{1}{9}$, nu $\frac{1}{1^{\frac{1}{4}}}$ deel houtgeest bevat. Dit is voldoende gebleken, het is onmogelijk om de houtgeest van de aethijlalcohol te scheiden, en hoe ook vermengd met gewoon gedistilleerd, blijft het als drank onverkoopbaar en ondrinkbaar.

De vraag, worden sterke drauken op groote schaal vervalscht met voor de gezondheid schadelijke stoffen, algemeen tot nog toe toestemmend beantwoord, moet blijkeus hetgeen in deze is aangevoerd ontkennend beantwoord worden, terwijl vervalsching met Amijl- en Methijl-alcohol in allen gevalle in de toekomst is uitgesloten. Vrees voor vervalsching is derhalve geen beletsel tegen accijnsverhooging, deze zal vervalsching niet ten gevolge hebben.

In het Leerboek der Staathuishoudkunde, $2^{\circ}$ druk, $2^{\circ}$ deel, bladz. 600-604, zet Mr. N. G. PIerson uitvoerig uiteen, waarom naar zijn oordeel, ook gegrond op cijfers hem verstrekt door den heer J. C. van Marken te Delft, het bedrag van den accijns iuvloed heeft op het alcoholverbruik, hoe verlaging van accijns noodwendig meerder gebruik moet ten gevolge hebben, en eveneens hoogere accijns minder verbruik, hoewel naar anderen beweren; de statistiek deze slotsom niet rechtvaardigt. $O p$ het drankverbruik werken echter zooveel oorzaken, dat het niet mogelijk is, den invloed van ééne 
oorzaak daarop langs statistischen weg te leeren kemnen. De Ned. Vereeniging tot afschaffing van alcoholhoudende dranken, is volgens haar adres aan de Tweede Kamer der Statcn-Generaal van oordeel dat de stelling, hoe hooger accijus, hoe minder verbruik wel opgant voor onschuldige stoffen zooals suiker, maar siet voor alcohol, omdat de alcoholist zijn alcoholverbruik, niet afhankelijk kan stellen van den prijs er van, doch van de behoefte welke zijn lichanm er aan heeft. Evenwel niet de alcoholist, de dronkaard wiens lichaam zoo onder den invloed van den alcohol staat, dat hij het drinken niet kan laten is de groote gebruiker van sterke dranken. Tegenover é é $n$ alcoholist staan honderden vrijwillige gebruikers, die hun gebruik wél afhankelijk zullen stellen van den prijs. Wanueer eene splitsing kon worden gemaakt zou het blijken, dat de alcoholisten te samen slechts een zeer klein deel van het totale verbruik voor hunue rekening hebben. Er moet onderscheid gemaakt worden tusschen alcoholisten, en vrijwillige driukers. De eersten kunneu alleen door zedelijken invloed herstellen van hunne verderfelijke neiging, terwijl wat de anderen betreft, allerlei invloeden en toestanden op hun alcoholverbruik invloed uitoefenen. Niet de grootste schare wordt de mantschappij anngedaan door de alcololisten, veel meer door die groote groep van gebruikers die slechts zoo uu eu dan bij voorkomende gelegenheden te veel drinken, deze vullen onze Arrondissements-Rechtbanken en hun drinkeu hourlt zeer zeker verband met den prijs van deu drank. Wanneer de voorstanders van afschaffing en geheelonthouding konden ophoudes, om in elken matigen gebruiker een aspirant alcoholist te zien, zou hunue werkzaamheid minder eenzijdig worden.

Overigeus wordt tegen accijnsverhooging anngevoerd, dat deze volgens de algemeene overtuiging geen invloed heeft op het gebruik, zonder vermelding van bepaalde feiteu die dat ourdeel kunnen staven. In het reeds genoemd adres van het Hoofdbestuur van de Ned. Vereeniging tot afschaffing van alcoholhoudende dranken, worden ten bewijze der stelling, dat accijnsverhooging geen invloed heeft op het verbruik van alcohol, vijf uitsprakeu aangehaald van drankbestrijders uit andere landen. Die uitspraken zijn eenstemmig, maar behelzen geen motieven, zij moeten op gezag worden aangenomen, en zullen op ons 
land niet toepasselijk zijn, wanneer het tegenovergestelde door feiten bewijsbaar is. Welke waarde kan men hechten, bijv. aan de stelling betrekkelijk Engeland, waar bij een hooge accijns, het verbruik slechts vijf liter per hoofd is. Moet niet integendeel worden aangenomen dat het lage gebruik een gevolg is van de hooge belasting? Wat ons land betreft wordt in het adres tot staving der stelling behalve de uitspraken van buitenlanders alleen angevoerd, "dat ontduiking van de wet; "vervalsching vande alcohol; het in kleiner hoe"veelheden tegelijk toedienen," eerder de gevolgen van "accijnsverhooging zijn geweest, dan afname van de ver"bruikte hoeveelheid." Wat het eerste punt betreft ontduiking van de wet, wat moet beteekenen meerdere accijnsontduiking naarmate de accijns hooger is geworden, deze bewering is geheel in strijd met de werkelijkheid. Wie daarover een onbevooroordeeld onderzoek wil instellen, zal gemakkelijk tot de overtuiging kumen, dat vóór 25 jaren en vroeger, in veel hoogere mate accijns op gedistilleerd werd ontdoken dan in den tegenwoordigeu tijd. Elk ervaren belastingambtenaar, zal daarover inlichting kumnen geven. Het tweede punt vervalsching van alcohol is reeds besproken. Het derde punt zal iedereen kunneu beamen, maar het bevat niet de geheele waarheid, het gevolg is niet alleen geweest "het in kleiner hoeveelheden "tegelijk toedienen, maar ook en in veel grooter mate het in minder gehalte toedienen van den drank." Dit laatste kon adressante bekend zijn; heeft zij het niet vermeld omdat zij gevoelde, dat zij daardoor met zich zelve in tegenspraak kwam? Heeft zij gevoeld dat het gehalte vau deu drank in zulke mate kan zijn verminderd, dat daarann in de eerste plaats het verminderd gebruik van alcohol is toe te schrijven en dat die vermindering van gehalte uitsluitend het gevolg moet ziju van accijnsverhooging?

Dat gedurende de achtereenvolgende accijusverhoogingen en teu gevolge van den hoogeren accijns, het gehalte der gedronken sterke dranken langzamerhand is gedaald en hoe groot het verschil is kan worden aangetooud. Oudere ambtegnaren der belastingen kunnen die geleidelijke gehaltevermindering hebben opgemerkt, hoewel die verlaging waarschijnlijk voor de drinkers zelve onmerkbaar is tot stand gekomen. Zij kau geen gevolg ziju van den 
invloed der werking van de drankwet, noch van die der Vereenigingen tot bestrijding van het drankgebruik. De maatregelen dier bestrijding strekken uitsluitend om minder drankverbruik te bewerken, maar hebben nimmer ten doel gehad om het alcobol-gehalte van den drank te verlagen. Bij eenig nadenken kan men tot geen ander besluit komen dan dat verlaging van gehalte uitsluiteud is veroorzankt door de achtereenvolgende accijnsverhoogingen, daar ook van de drinkers geen aandrang is uitgegaan om den drank slapper te maken. Volgens de accijnswetten van kracht, vóór de wet ran 1862, in werking getredew den $5^{\mathrm{n}}$ Juni 1863 , bedroeg de accijns op binnenlands gedistilleerd f 12 plus rijksopcenten, zegelrecht en gemeenteaccijns, per hectoliter van 10 graden op den Nederlandschen vochtweger, bij eene warmte van $55^{\circ}$ Fahr $^{t}$., welk gehalte als eenheid aangenomen, werd genoemd gedistilleerd van $100 \mathrm{pCt}$. Dat gehalte was gelijk an gedistilleerd dat 50,7 pCt. alcohol bevat volgens de gehaltebepaling naar de Wet van 1862. Daarann is het toe te schrijven dat in den regel bij de prijsberekening in den groothandel met grossiers, en ook voor de kleinere afnemers in sommige plaatsen van ous land, b.v. in Noordholland, als eenheidsprijs nog genomen wordt de hectoliter van 50,7 pCt. Een bewijs hoe moeielijk handelsusantiën, zich aanpassen aan veranderde toestanden.

Bij de Wet van 1862 werd de accijns vastgesteld op $f 22$ zonder rijksopcenten en zouder zegel, maar werd daarop nog gemeente-belasting geheven. De belasting is toen niet verhoogd, wel op 1 Maart 1864 tot $\mathrm{f} 35$ plus gemeente-belasting, der-. halve eene aanmerkelijke verhooging van f 13 per H.L. Den $1^{\text {n }}$ Mei 1866 werd wederom de Rijksaccijns verhoogd tot $\mathrm{f} 50$ de H.L. Dat was geen accijnsverhooging in het algemeen. Op denzelfden datum werd volgens K. B. van 4 Aug. 1865 No. 39, met uitzondering voor enkele gemeenten, tot uitvoering der Wet van 7 Juli 1865 (Stbl. 79) de gemeente-accijns, die tot verschillende bedragen door de gemeenten geheven werd, afgeschaft. Het totaal der belasting was in de onderscheidene gemeenten ongelijk, maar bedroeg vooral in de groote gemeenten, veelal meer dan $f$ s 0 .

Ik heb recds gezegd dat de oudere ambtenaren der belastingen 
omtrent de gehalteverlaging hunne oudervinding kunuen raadplegen; mij persoonlijk heeft de crvaring gelecrl, dat gedurende ruim 25 jaren het gehalte van deu drank, zooals die gedronken wordt van gemiddeld 44 aे $45 \mathrm{pCt}$. alcohol tot gemiddeld 39 a 40 pCt., waarschijnlijik nog tot eeu lager gemiddelde is gedaald. In 1863 toen de nieuwe accijns-wetgeving op gedistilleerd is iv werking gekomen, warbij een nieuw stelsel van gehalte-bepaling werd ingevoerd, heeft een ontvanger een tarief voor de herleiding tot hoeveelheden van 50 pCt. samengesteld, bruikbaar voor alle hoeveelheden van af 44 tot 54 pCt. alcohol. De sterkte van 44 pCt. was toen de lagste, die bij jenever, brandewiju, cognac, enz. voorkwam. Likeuren, die van lager gehalte zijn, blijven buiten anmerking, die worden gemakt van reeds veraccijnsd gedistilleerd eu behoeven voor de accijus-berekening niet tot hoeveelheden van 50 pCt. te worden herleid.

Gehalten vau minder dan 4.4 pCt. kwamen derhalve toen niet voor eu vele jaren daarna evenmin. Het geschreven boek werd dagelijks gebruikt van 1863 tot 1879 , toen was het door het vele gebruik versleten, en om het gemak dat het verschafte te behouden werd het gedrukt en is het in 1879 uitgegeven bij de Gebroeders Van Cleef te 's Gravenhage. Reeds in 1879 was er cenige verlaging van gehalte merkbaar, maar dat werd niet in aanmerking genomen. Voor het aannemen van een te verwachteu doorgaande verlaging van gehalte bestond toen geen aanleiding, het gedrukte boek bevatte even als het geschrevene als minimum, hoeveelheden van $4.4 \mathrm{pCt}$. Dat was zooals later bleek een fout, want spoedig n de uitgifte, kwam verlaging van het gehalte meer merkbaar aan den dag, en wel in die mate dat de afzet verminderde en langzamerhand bijna geheel ophield. Het werk was gedeeltelijk onbruikbaar geworden, omdat het meerendeel der daarbij belanghebbenden meer gehalten beneden 4i. pCit. dan daarboven moesten herleiden tot $50 \mathrm{pCt}$. De aflevering door branden van moutwijn aan distillateurs, en van jenever en brandewijn door distillateurs aan haudelaars in het groot, geschiedt iu den regel nog op een gehalte van 44-47 pCt., daarvoor is het werk nog bruikbaar. De eerste accijnsverhooging had derhalve plaats op 1 Maart 1864 met f 13 de HL. Het gevolg daarvan is geweest dat toen de borrels van 3 cent, bij uitzondering van 4 cent, 
in tapperijen en kroegen vo6r dien tijd algemeen in gebruik, zijn vervangen door borrels van 5 cent. Velen zullen zich dat, evengoed als $i k$, nog wel herinneren. Verlaging van het gehalte van den drank $\mathrm{kwam}$ toen nog niet voor. Door deze sterke verhooging van accijns, is alzoo door den tapper en kroeghouder de prijs van den borrel verhougd, wardoor zij den verhoogden inkoopsprijs terugvondeu.

Ook de daarop gevolgde accijnsverhooging in 1869 van $\mathrm{f} 50$ op $f 53$ had nog geen verlaging van het alcoholgehalte tot gevolg, en daar de tappers het evenmin raadzaain vonden, den prijs per borrel weder te verhoogen, werden om het verschil in inkoopsprijs van $\mathrm{f} 3$ per HL. terug te vinden, de glazeu kleiner genomen, Minder in de glazen te doen ging niet, de gebruikers verlangen het glus tot deu rand gevuld. De tapper die daaran niet voldoet, zou ziju nering spoedig zien verloopen.

Het is mij niet bekend of bij de volgende accijnsverhooging in 1877 van $f 53$ op $f 57$, uogmaals de glazen zijn verkleind, waarschijnlijk niet. men had ook daarmede reeds de greus bereikt, maar wel is mij gebleken, dat daarna spoedig merkbaar, tot gehalteverlaging vau den drank is overgegnau, en dat de accijnsverhooging in 1877, daartoe de eerste aauleiding heeft gegeveu, terwijl de volgende accijusverhoogingen in 1887 en 1893, hetzelfde gevolg hebben gehad en wel in die mate, dat wanneer men nu een algemeen bruikbaar tarief voor de herleiding weuschte samen te stellen, dat zou moeten nanvangen bij hoogstens 38 pCt. in plants van bij 44 pCt.

Voor het vaststellen van het gemiddeld gehalte van jenever, brandewijn en bitter zooals die in 1902 gedronken werden, geeft het reeds vermeld rapport van onderzoek door prof. Wefers Bettink de noodige gegeveus. Vau de 82 monsters afkomstig uit tapperijen in alle deelen van het Rijk, die onderzocht rijn op foesel en houtgeest, is ook het alcoholgehalte bepaald. 47 van de 82 onderzochte monsters, hadilen een gehalte van minder dan 40 pCt., één zelfs vaı 24 pCt., en allen te samen een gemiddeld gehalte van 38,71 pCt., bij de berekening waarvan, buiten aanmerking bleef een monster bitter van 56,5 pCt., dat niet onvermengd gedronken wordt. Ook moet worden in aanmerking genomen dat, (op welke wijze dau ook), bij 12 
van die monsters houtgeest was gevoegd waardoor de bevonden gemiddelde sterkte van 38,71 pCt., nog te hoog is. Volgens het onderzoek eveueens in 1902 ingesteld, vermeld in het "Leerboek der Staathuishoudkunde" van Mr. Pierson, $2^{\mathrm{e}}$ druk, $2^{\text {e }}$ deel, blz. 602, werd toen het alcoholgehalte van jenever, gemiddeld vastgesteld in Delft op 34,6 pCt., 's Gravenhage 36,9 pCt., Rotterdam 37,3 pCt., Amsterdam 38,7 pCt., Middelburg 39,2 pCt., Enkhuizen 37,3 pCt., Sneek 4i, 6 pCt., Amersfoort 40,6 pCt., Veendam 39.4 pCt. eu Arnhem 33,9 pCt., gemiddeld voor die tien plartsen $37,95 \mathrm{pCt}$. Ook van deze monsters was de laagste 24 pCt. sterk. Naar deze uitkomsten kan men de sterkte van den thaus gedronken drank (jenever en brandewijn) veilig stellen op gemiddeld 38 pCt.

Het staat derhalve vast dat na 1877 , het gehalte van sterken drank, zooals die gedronken wordt, met minstens gemiddeld 5 pCt. is verminderd, en dat het gemiddeld gehalte van 1863 tot 1877 , toen nog geen accijnsverhooging daarop invloed kon uitoefenen stationnair was.

Het verminderd alcoholverbruik kan afgeleid worden, uit de hierua volgende officieele cijfers, genomen uit: "Statistiek van het Kon. der Nederlanden. Bescheiden betreffende de geldmiddelen", afdeeling belastingen.

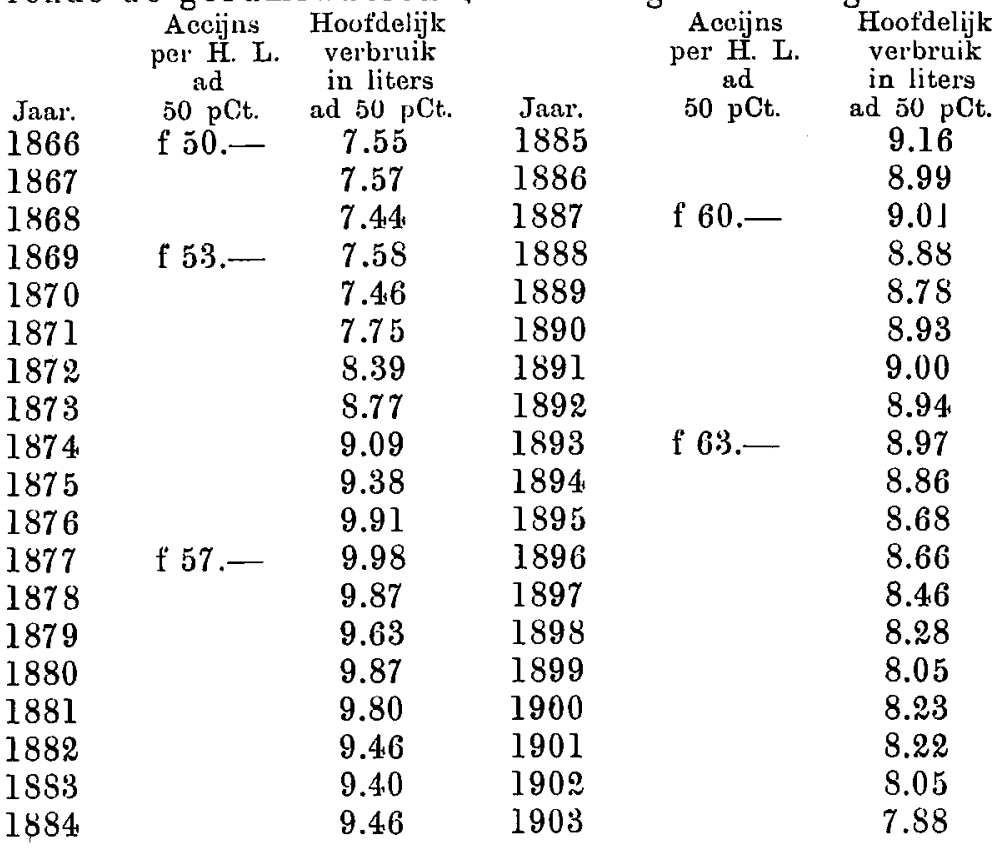


Vóór 1866 werd geen officieele statistiek van het alcoholverbruik opgemaakt. Deze cijfers toonen geen geregeld verloop, noch in klimming, noch in daling, de juisheid er van is echter onbetwistbaar. Deze statistiek moge in hare onderdeelen enkele fouten kunnen vertoonen, de cijters die het verbruik per hoofd over het geheele Rijk aangeven, geven een juist beeld van den werkelijken toestand. Bestond er een uitgebreide accijnsfraude, dan zou het verbruik in werkelijkheid grooter zijn, maar die bestaat niet; accijus outduiking is niet van zoodanige beteekenis, dat zij van invloed zou zijn op de cijfers voor het gemiddeld verbruik. Dat ze geen geregeld beloop vertoonen is niet te verwonderen. Afgescheiden van de werking en den invloed van de "Drankwet" en van de Vereenigingen die het mlsbruik bestrijden, bestann er verschillende oorzaken die op het verbruik van invloed ziju. Bovendien zijn de vijf achlereenvolgende accijnsverhoogingen, waarbij op deu dag der in werking treding, geen bijbetaling van den voorrand werd gevorderd, van invloed geweest op de regelmaat der cijfers van verbruik, doordien te voren groote voorraden werden veraccijnsd. Ook heeft de wet van 31 Dec. 1898 (Stbl. No. 286), in werking getreden den $1^{\text {" Juli }}$ 1900, op de cijfers eenigen invloed uitgeoefend. Door die wet werd een eind gemaakt aan de belasting ontduiking, waartoe de wet van 1862 door te groote toegevendheid, sommige branders in Limburg en Noordbrabant, die eene verouderde werkwijze volgden, in staat stelde. Daardoor is het verbruik per hoofd van veraccijnsd gedistilleerd in Limburg gestegen, hetgeen uatuurlijk ook van eenigen invloed is geweest op het cijfer van verbruik voor het geheele Rijk.

De voornaamste oorzaak is meerdere of mindere welvaart der bevolking. Daaraan is het waarschijnlijk toe te schrijven dat van 1870 het verbruik geregeld is gestegen tot 1877 van 7,46 tot 9,98 liter. Het zijn de jaren waarin de eerste algemeene verhooging van arbeidsloonen plaats had. Geen wonder dat zulks vermeerdering van drankverbruik ten gevolge had. De arbeiders waren toen nog minder georganiseerd en loonsverhooging, waarvan men te voren nimmer hoorde, was toen een zeer bijzondere gebeurtenis; men had minder dan thans te lijdeu val werkloosheid, men kon een gedeelte der loonsverhooging voor zijn genoegen besteden en dat vond men in de herberg. 
Dat duurde niet lang, de huishoudelijke uitgaven, kwamen in evenwicht met de meerdere verdiensten; door betere organisatie kwam de werkman meer tot het besef vau hetgeen hem dienstig was, verdere loonsverhooging harl niet meer hetzelfde gevolg als de eerste, en het verbruik verminderde weer tot de oorspronkelijke hoeveelheid. Wanneer men derhalve uit de cijfers van 1877, 9,98 liter, eu 1903, 7,88 liter, de gevolgtrekking maakte dat sedert 1877 het gemiddeld verbruik met ruim twee liters per hoofd is gedaald, zou dat evenveel waarde hebben, als aan te nemeu dat het verbruik niet is verminderd, omdat het in 1903 hooger was dan in de jaren 1866-1871. Deze twee elkaar tegensprekende gevolgtrekkingen, toonen alleen aan, dat men van statistieke cijfers met oordeel moet gebruik maken.

Zal eene raming vau de daling vau het gebruik eenigen goeden grond hebben, dan moet een gemiddelde worden aangenomen. Ik neem daarvoor het jaar 1873, met een verbruik van 8,77 liter, 1887 toen de accijns tot $\mathrm{f} 60$ is verhoogd, met 9,01 liter en het gemiddelde van de drie laatst bekende jaren $1901-1903$ is 8,05 liter, wanruit dau zou volgen dat in den loop der jaren het verbruik gemiddeld pl. m. een liter per hoofd is verlaagd, alzoo met een negende deel.

Zooveel alcohol wordt er nu als drank minder verbruikt, maar er moet onderscheid gemaakt worden tusschen alcohol verbruik en verbruik van sterken drank, dat niet hetzelfde is.

Als het vaststaat, en ik ben overtuigd dut het eeu niet te weerspreken feit is, dat sedert omstreeks 1878 de drauk die gedronken wordt geregeld in sterkte is verminderd; van gemiddeld pl. m. $45 \mathrm{pCt}$. is gedaald tot $40 \mathrm{pCt}$. en minder, eeu verschil derhalve van pl. m. $\frac{1}{9}$ deel, dan volgt daaruit dat het gebruik van sterken drank, nagenoeg gelijk is gebleven, dat er in 1903 nagenoeg eveuveel is gedrouken per hoofd der bevolking als in 1873. Het verschil is, dat ieder glas drank gemiddeld minder alcohol bevat dan vroeger, zooals is angetooud een gevolg rande opvolgende accijnsverhoogingen.

Welke exeptiën meu daartegen ook aanvoert, men ontkomt niet anu deze conclusiën: Stel dat het alcoholverbruik per hoofd, gedurende een zeker nautal jaren, met $1 / a$ deel is verminderd, eu in denzelfiden tijd, de sterkte van de gedronken drank met $1 / \mathrm{b}$ dẹel is verlaagd, dan blijkt daaruit 
]$^{0}$. dat wanneer de warde van a en b gelijk is, het minder gebruik van alcohol geheel is veroorzaakt door accijnsverhoogingen;

$2^{\circ}$. dat wanneer a kleiner is dan $b$, het minder verbruik voor $1 / b$ deel het gevolg is vau accijnsverhooging, terwijl het overige deel der vermindering aan andere oorzaken moet worden toegeschreven;

$3^{0}$. dat wanneer a gróter is dan b, de verlaging van het gehalte, geen aanleiding heeft gegeven tot minder verbruik van ten volle $1 / b$ deel, maar het lnge gehalte tevens oorznak is geweest, tot méér drankverbruik.

Uit de statistieke cijfers van het alcohol verbruik per hoofd, volgt echter, dat het geval sub 3 niet is voorgekomen, zoodnt alleen de gevallen sub 1 en 2 overblijven en dat voor de waarde van b het cijfer 9 aannemende, gelijk staande met eene vermindering per hoofd van pl. m. een liter moet worden aangenomen, dat tengevolge van de accijnsverhoogingen, het alcoholverbruik met pl. m. é́n liter is verminderd.

$\mathrm{Zal}$ verdere verhooging hetzelfde gevolg hebben, of is reeds de grens bereikt, zoodat in die richting niet verder kan worden gegaan, zooals met verhooging van den prijs, en met het toedieuen van geringer hoeveelheid, reeds dadelijk na de beide ecrste verhoogingen de grens was bereikt. Integendeel, waarom zou in Nederlaud, niet denzelfden toestand kunnen ontstaan, als in zcovele andere landen, waar de alcohol als regel niet dan in zeer verdunden toestand wordt gedronken? Zij die Parijs wel eens bezoeken, kunnen weten hoe de Parijzeuaar zich verwoudert over die Hollanders, die dat bijtende vocht, zoo maar onaangelengd innemen.

En zou darmede niet veel gewonnen worden? De geneeskundigen zijn eenstemmig in hun oordeel dat de nadelige werking van alcohol op het menschelijk lichaam vermindert, narmate de alcohol in meer verslapten toestand wordt gedronken.

Heb ik door dit opstel de Vereenigingen tegen het misbruik van sterken drank, willen weerhouden van voortzetting, door zoo hooge begiuselen ingegeven werkzaamheid? Neen, maar ik wilde hun aantoonen, dat ze in den fiscus een krachtigen bondgenoot hebben, veel krachtiger dan zij gewoon zijn te veronderstellen. - - Ik wilde hun uitnoodigen aan dien bondgenoot voortuan de hand te reiken, in plaats van, zoonls meermalen geschiedt, hem te bestrijden.

$$
\text { Assen, Maart } 1905 .
$$

H. Hemtjans. 